\title{
PEMBERIAN MADU PADA KLIEN DIARE DENGAN MASALAH KEPERAWATAN PENINGKATAN FREKUENSI BAB DI DESA RAJABASA LAMA LAMPUNG TIMUR
}

DOI: https://doi.org/10.33024/jkpm.v4i5.2836

$$
\text { Intan Putri }{ }^{1} \text {, Setiawati }{ }^{2^{*}}
$$

${ }^{1}$ Program Studi Ilmu Keperawatan Universitas Malahayati

${ }^{2}$ Mahasiswa Program Profesi Ners Universitas Malahayati

Disubmit: 10 Juni 2020 Diterima: 03 Mei 2021 Diterbitkan: 03 Oktober 2021

Email Korespondensi: setiawati@malahayati.ac.id

\begin{abstract}
ABSTRAK
Diare di Indonesia merupakan penyakit endemis dan juga merupakan penyakit potensial Kejadian Luar Biasa (KLB) yang sering disertai dengan kematian. Angka kejadian diare Provinsi Lampung khususnya di Lampung Timur yaitu 21.588 kasus. Madu sebagai obat tradisional dengan berjuta khasiat sudah dikenal sejak zaman dahulu, bahkan Al-Quran menjelaskan manfaat lebah dan produknya sebagai penyembuh berbagai macam penyakit. Termasuk salah satunya diare. Madu adalah agen non alergi, nutrisi alami yang tinggi nilai antioksidan, anti-inflamasi, dan memiliki aktivitas antibakteri. Tujuan penelitian, untuk mendapatkan pengalaman dan kompetensi lebih dalam pemberian asuhan keperawatan komprehensif pemberian madu terhadap penurunan frekuensi bab. Adapun intervensi yang dilakukan dengan pemberian madu $1 \mathrm{sdm}$ dengan dilarutkan kedalam air $100 \mathrm{cc}$ selama 5 hari diminum secara rutin 3 kali sehari. Terdapat penurunan frekuensi bab setelah diberikan madu pada anak diare. Dengan demikian pemberian madu pada anak diare untuk menurunkan frekuensi buang air besar sangat efektif.
\end{abstract}

Kata Kunci: Diare, Madu, Nutrisi

\begin{abstract}
Diarrhea in Indonesia is an endemic disease and is also a potential disease of Extraordinary Events (KLB) which is often accompanied by death. The incidence of diarrhea in Lampung Province, especially in East Lampung is 21,588 cases. Honey as a traditional medicine with millions of benefits has been known since ancient times, even the Koran explains the benefits of bees and their products as a cure for various diseases. Including one of them diarrhea. Honey is a nonallergic agent, a natural nutrient that is high in antioxidant value, antiinflammatory, and has antibacterial activity. The aim of the study was to gain more experience and competence in the provision of comprehensive nursing care for honey to reduce chapter frequency. The interventions carried out by giving 1 tablespoon honey with dissolved into 100 cc of water for 5 days drink routinely 3 times a day. There is a decrease in the frequency of chapters after giving honey to children with diarrhea. Thus giving honey to children with diarrhea to reduce the frequency of chapters is very effective.
\end{abstract}

Keywords: diarrhea, honey, nutrient 


\section{PENDAHULUAN}

Penyakit diare hingga saat ini masih menjadi masalah kesehatan masyarakat di dunia dengan tingginya angka mortalitas dan morbiditas. Menurut data WHO (World Health Organization) diare adalah penyebab nomor satu kematian anak dibawah lima tahun (balita) di seluruh dunia yang mengakibatkan 842.000 kematian, 361.000 diantaranya merupakan balita.

Diare di Indonesia merupakan penyakit endemis dan juga merupakan penyakit potensial Kejadian Luar Biasa (KLB) yang sering disertai dengan kematian. Pada tahun 2016 terjadi 3 kali KLB diare yang tersebar di 3 provinsi, 3 kabupaten, dengan jumlah penderita 198 orang dan kematian 6 orang (CFR $3,04 \%)$.

Prevalensi diare pada balita di Provinsi Lampung pada tahun 2013 adalah 8\% sedangkan pada tahun 2018 mengalami peningkatan mencapai 10\%. Angka kejadian diare Provinsi Lampung khususnya di Lampung Timur yaitu 21.588 kasus.

Masyarakat Indonesia sejak dahulu telah menggunakan obat tradisional sebagai pengobatan. Hal ini didukung dengan keragaman hayati yang dimiliki baik hewan maupun tumbuhan dibandingkan negara lain. Penelitian tentang obat tradisional sebagai antidiare yang memiliki efek anti-inflamasi dan antibakteri dengan kombinasi Zinc dan ORS efektif dalam mengurangi frekuensi diare Selain tumbuhan, hewan juga dapat menjadi obat tradisional salah satunya lebah sebagai penghasil madu.

Madu sebagai obat tradisional dengan berjuta khasiat sudah dikenal sejak zaman dahulu, bahkan Al-Quran menjelaskan manfaat lebah dan produknya sebagai penyembuh berbagai macam penyakit. Termasuk salah satunya diare. Madu adalah agen non alergi, nutrisi alami yang tinggi nilai antioksidan, antiinflamasi, dan memiliki aktivitas antibakteri.

Berdasarkan latar belakang ini, maka peneliti tertarik melakukan penelitian tentang Asuhan Keperawatan Komprehensif Pada Klien Diare Dengan Masalah Keperawatan Peningkatan Frekuensi BabDengan Pemberian Madu Di Desa Rajabasa Lama Lampung Timur.

\section{MASALAH}

Alasan saya memilih tempat intervensi dan demonstrasi pemberian madu terhadap penurunan frekuensi bab di Desa Rajabasa Lama Lampung Timur karena angka kejadian diare Provinsi Lampung khususnya di Lampung Timur yaitu 21.588 kasus., dimana tujuan umum diharapkan mendapatkan pengalaman dan kompetensi lebih dalam pemberian Asuhan Keperawatan Komprehensif Pemberian Madu terhadap penurunan frekuensi bab. Tujuan khusus dalam kegiatan yaitu diketahui asuhan keperawatan sesuai dengan peminatan, yang meliputi pengkajian, penegakan diagnosa, perumusan rencana keperawatan, intervensi, dan evaluasi, diketahui analis jurnal untuk menentukan salah satu intervensi yang akan diberikan sesuai masalah keperawatan yang diangkat, diketahui intervensi keperawatan sesuai dengan hasil telaah jurnal, diketahui implementasi hasil aplikasi intervensi keperawatan sesuai jurnal pada pasien. 


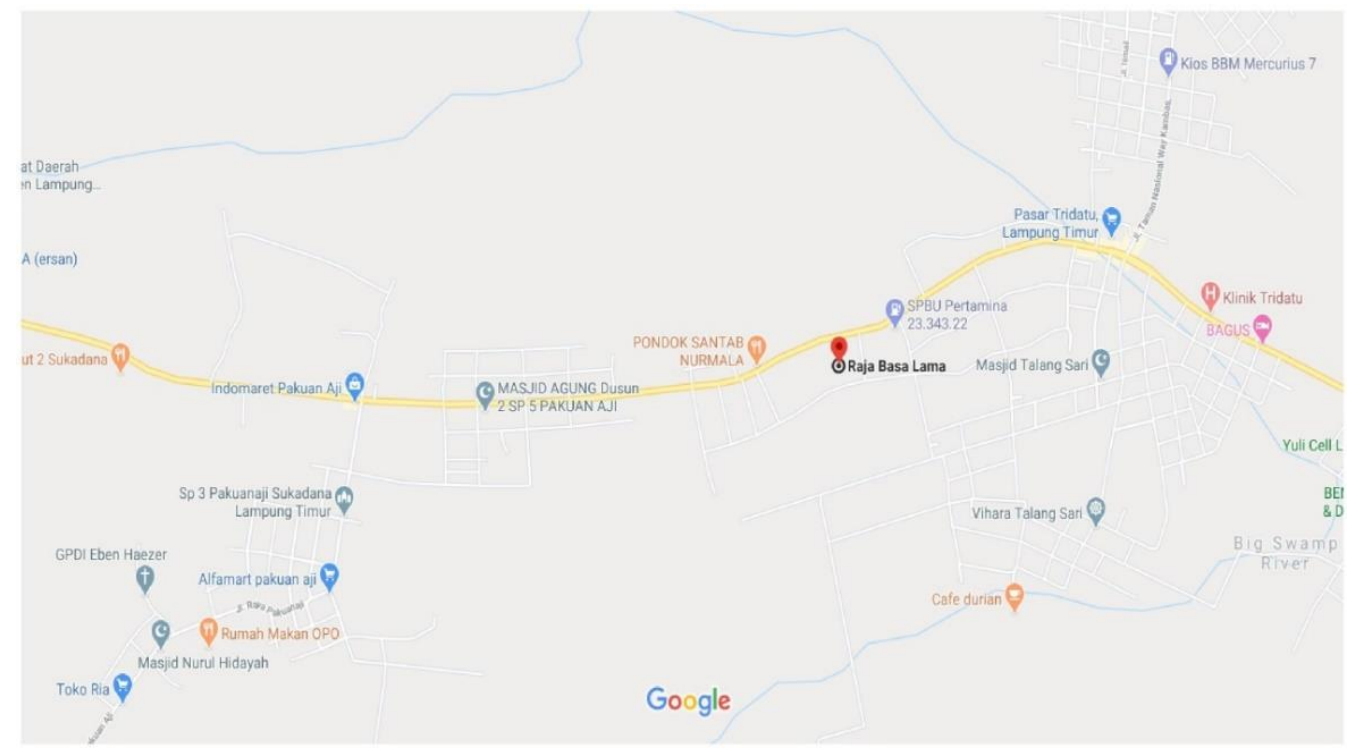

Gambar 2.1 Lokasi Klien di Desa Rajabasa Lama Lampung Timur

\section{METODE}

1) Tahap Persiapan

Tahap persiapan dari kegiatan adalah pembuatan pre planning, persiapan tempat serta alat dan bahan lainnya disiapkan oleh peneliti. Kemudian peneliti menjelaskan maksud dan tujuan, menanyakan kesiapan klien, dan menjaga privasi klien, serta menjelaskan dan mendemonstrasikan prosedur kerja pemberian madu untuk persiapan yang baik dan benar.

2) Tahap Pelaksanaan

Pada hari pertama melakukan pre test dengan mengkaji dan mengobservasi frekuensi bab klien. Kemudian, melaksanaan intervensi pemberian madu. Madu sebanyak $100 \mathrm{ml}$ diminum rutin tiga kali sehari sesudah makan selama 5 hari. Kemudian pada hari terakhir melakukan post test dengan mengkaji dan mengobservasi frekuensi bab klien.

3) Evaluasi

a. Struktur

Klien sebanyak 1 orang yaitu anak perempuan. Setting tempat sudah sesuai dengan rencana yang dibuat serta alat dan bahan untuk mendemonstrasikan pemberian madu sudah tersedia dan sudah digunakan sebagaimana mestinya. Peran peneliti sudah sesuai dengan tugasnya, baik sebagai penanggung jawab, observator, fasilisator, dan dokumentasi. Penggunaan bahasa yang dipraktikkan sudah komunikatif dalam penyampaianya, klien dapat memahami apa yang sudah disampaikan dan dapat mempraktikkan kembali yang sudah didemonstrasikan.

b. Proses

Pemberian intervensi madu dimulai pada hari Senin 03 Mei 2020 selama 5 hari. c. Hasil

Hasil evaluasi pada klien diperoleh penurunan frekuesensi bab sesudah pemberian madu. 


\section{HASIL DAN PEMBAHASAN}

Tabel 4.1

Frekuensi Bab Sebelum dan Sesudah Pemberian Madu

\begin{tabular}{ccc}
\hline $\begin{array}{c}\text { Pemberian } \\
\text { Madu }\end{array}$ & Pretest & Posttest \\
\cline { 2 - 3 } & $5 x /$ Cair & $2 x /$ Lembek \\
\hline
\end{tabular}

Berdasarkan Tabel 4.1 menunjukkan hasil evaluasi pada klien, dimana klien mengalami penurunan frekuensi bab setelah dilakukan pemberian madu sebanyak $100 \mathrm{ml}$ selama 5 hari berturut-turut, diminum tiga kali sehari sesudah makan. Diperoleh frekuensi bab sebelum diberikan madu (pretest) yaitu $5 x /$ Cair dan frekuensi bab setelah diberikan madu (posttest) yaitu $2 x /$ Lembek, dimana mengalami penurunan sebanyak 2x/Lembek.

Berdasarkan hasil penelitian Sofyan Cholid dengan judul Pengaruh pemberian madu pada diare akut. Menggunakan metode uji klinis (randomized controlled trial), dengan menggunakan 70 sample, 35 anak kelompok control dan 35 anak kelompok sumplentasi madu. Di dapatkan hasil Perbedaan frekuensi diare antara 2 kelompok terjadi padahari ke-2. Perawatan hari ke-3 kelompok suplementasi madu mengalami kesembuhan 50\%, kelompok kontrol 25\%. Mak dapat disimpulkan Pemberian madu terbukti menurunkan frekuensi diare pada hari ke 2,4, dan 5, memperpendek lama perawatan serta kesembuhan 50\% terjadi dihari ke-3.

Diare saat ini masih merupakan masalah kesehatan yang sering terjadi pada masyarakat. Padahal berbagai upaya penanganan, baik secara medis maupun upaya perubahan tingkah laku dengan melakukan pendidikan kesehatan terus dilakukan. Namun upaya-upaya tersebut belum memberikan hasil yang menggembirakan. Setiap tahun penyakit ini masih menduduki peringkat atas, khususnya di daerah-daerah miskin. Diare juga merupakan penyebab utama kesakitan dan kematian pada anak di berbagai negara (Widoyono, 2011). Diare dapat menyerang semua kelompok usia terutama pada anak. Anak lebih rentan mengalami diare, karena sistem pertahanan tubuh anak belum sempurna.

Diare pada bayi dan balita ini dapat disebabkan oleh beberapa faktor diantaranya: yaitu infeksi, malabsorbsi, makanan, dan psikologis anak. Infeksi enteral merupakan infeksi saluran percernaan, yang menjadi penyebab utama diare pada anak. Infeksi enteral disebabkan karena bakteri, virus dan parasit. Sedangkan infeksi parenteral merupakan infeksi dari luar pencernaan seperti otitis media akut (OMA), bronkopneumonia, ensefalitis. Keadaan ini terutama terdapat pada bayi dan anak berumur di bawah 2 tahun.

Dampak masalah fisik yang akan terjadi bila diare tidak diobati akan berakibat kehilangan cairan dan eletrolit secara mendadak. Pada balita akan menyebabkan anoreksia (kurang nafsu makan) sehingga mengurangi asupan gizi, dan diare dapat mengurangi daya serap usus terhadap sari makanan. Dalam keadaan infeksi, kebutuhan sari makanan pada anak yang mengalami diare akan meningkat, sehingga setiap serangan diare akan menyebabkan kekurangan gizi. Jika hal ini berlangsung terus menerus akan menghambat proses tumbuh kembang anak. Sedangkan dampak psikologis terhadap anak-anak antara lain anak akan menjadi rewel, cengeng, sangat tergantung pada orang terdekatnya.

Analisis peneliti didapatkan adanya penurunan frekuensi Bab pada klien. Hal ini bisa terjadi dikarenakan kandungan madu yang dapat menghambat pertumbuhan bakteri. Selain itu madu dapat menggantikan komposisi glukosa dalam cairan rehidrasi oral. Madu juga cepat diserap dalam organ pencernaan 
untuk sampai ke dalam darah. Madu adalah cairan alami yang umumnya mempunyai rasa manis yang dihasilkan oleh lebah madu. Madu terbukti memiliki beberapa efek antibakteri, antiinflamasi, dan antioksidan. Pemberian madu mampu menurunkan frekuensi diare dengan efek antioksidan, flavonoid berperan dalam memperbaiki absorbsi cairan dan elektrolit. Efek prebiotik madu meningkatkan pertumbuhan bakteri endogen sehingga mampu melawan pertumbuhan bakteri patogen. Sedangkan efek antibakteri madu menghasilkan hidrogen peroksida yang juga mampu melawan pertumbuhan bakteri patogen.
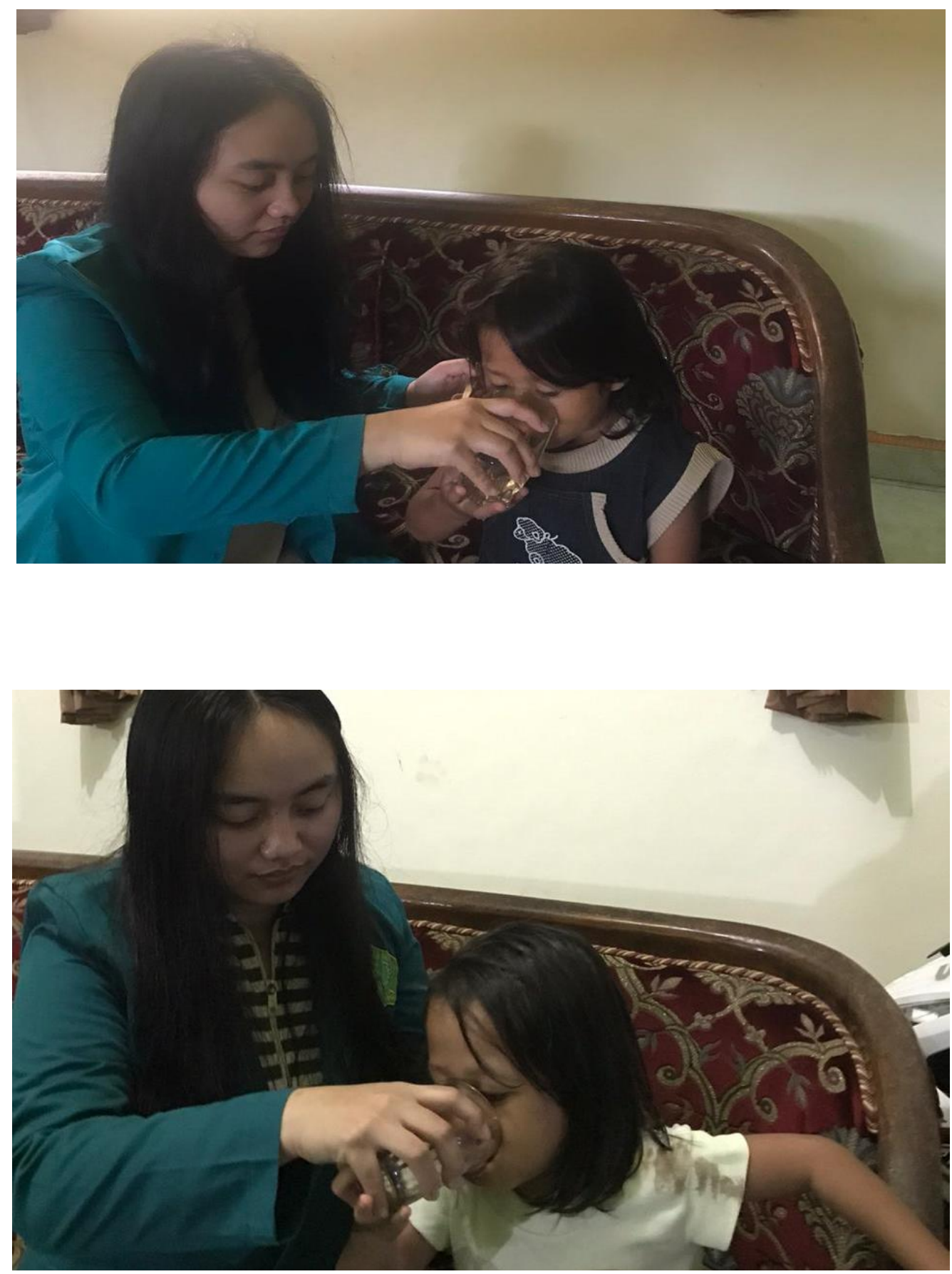

Gambar 4.1 Pelaksanaan Intervensi Pemberian Madu 


\section{KESIMPULAN}

Saat dilakukan pengkajian pada klien ditemukan data yang sesuai dengan tinjauan teori untuk masalah diare pada klien. Berdasarkan data yang diperoleh, peneliti mendapatkan diagnosa keperawatan yang harus ditangani yang akan dijadikan suatu masalah. Pada intervensi keperawatan yang dilakukan pada klien yaitu sesuai dengan diagnosa keperawatan dan dilakukan pemberian madu. Implementasi Keperawatan yang dilakukan berdasarkan pada intervensi yang telah direncanakan.

Pemberian madu dapat menurunkan frekuensi Bab pada klien. Hal ini bisa terjadi dikarenakan kandungan madu yang dapat menghambat pertumbuhan bakteri. Selain itu madu dapat menggantikan komposisi glukosa dalam cairan rehidrasi oral. Madu juga cepat diserap dalam organ pencernaan untuk sampai ke dalam darah. Madu adalah cairan alami yang umumnya mempunyai rasa manis yang dihasilkan oleh lebah madu. Madu terbukti memiliki beberapa efek antibakteri, antiinflamasi, dan antioksidan. Pemberian madu mampu menurunkan frekuensi diare dengan efek antioksidan, flavonoid berperan dalam memperbaiki absorbsi cairan dan elektrolit. Efek prebiotik madu meningkatkan pertumbuhan bakteri endogen sehingga mampu melawan pertumbuhan bakteri patogen. Sedangkan efek antibakteri madu menghasilkan hidrogen peroksida yang juga mampu melawan pertumbuhan bakteri patogen.

\section{DAFTAR PUSTAKA}

Andayani, Rifka. (2018). Madu Dengan Oral Rehydration Salts Dan Larutan Madu Efektif Terhadap Penurunan Frekuensi Diare Dan Lama Rawat Pada Anak.

Cholid, Sofyan. (2011). Pengaruh Pemberian Madu Pada Diare Akut.

Dinas Kesehatan Provinsi Lampung. (2016). Profil Kesehatan Lampung. Dinkes Lampung.

Nelson. (2012). Ilmu Kesehatan Anak. Edisi 15. Jakarta: EGC.

Ngastiyah. (2014). Perawatan anak sakit edisi 2. Jakarta : EGC

Nurarif, Amin Huda \& Kusuma, Hardi. (2013). Aplikasi Asuhan Keperawatan Berdasarkan Diagnosa Medis \& NANDA NIC NOC Jilid 2. Jakarta: EGC.

Nursalam. (2008). Asuhan Keperawatan Bayi dan Anak (untuk bidan dan perawat). Edisi 2. Jakarta: Salemba Medika.

Pupitayani, Dian. (2014). Pengaruh Pemberian Madu Terhadap Penurunan Frekuensi Diare Anak Balita Di Desa Ngumpul Jogoroto Jombang.

Qur'an Surat An-Nahl: 68-65. (2015). Departemen Agama Rl. Jakarta: PT. Syamil Cipta Media.

Soedjas, triwibowo. (2011). Bila Anak Sakit. Yogyakarta: Amara Books

Widoyono. (2011). Penyakit Tropis Epidemiologi, Penularan, Pencegahan \& Pemberantasannya Edisi 2. Jakarta: Erlangga 